\title{
Microbial Muses: Threads of Our Inner Wisdom
}

\author{
Susan E. Erdman
}

check for updates

Citation: Erdman, S.E. Microbial Muses: Threads of Our Inner Wisdom. Challenges 2021, 12, 10. https:// doi.org/10.3390/challe12010010

Academic Editors: Palmiro Poltronier and Susan L. Prescott

Received: 19 December 2020

Accepted: 23 March 2021

Published: 25 March 2021

Publisher's Note: MDPI stays neutral with regard to jurisdictional claims in published maps and institutional affiliations.

Copyright: (C) 2021 by the author. Licensee MDPI, Basel, Switzerland. This article is an open access article distributed under the terms and conditions of the Creative Commons Attribution (CC BY) license (https:// creativecommons.org/licenses/by/ $4.0 /)$.
Massachusetts Institute of Technology, Cambridge, MA 02139, USA; serdman@mit.edu

\begin{abstract}
Spiritual journeys unveil our inner wisdom to help us navigate traumatic life events. Scientific evidence implicates a gut-immune-brain axis in our sense of self, raising the possibility that our microbial partners and hormone oxytocin offer a sense of connectedness and liberate our ancestral archives to sustain us during challenging times.
\end{abstract}

Keywords: microbiome; oxytocin; microRNA; meditation; inner wisdom

\section{Introduction}

Seeking connectedness during challenging times, many of us turn to meditations for guidance. Today's social and environmental upheavals require resiliency and lead us to soul searching to navigate traumas. Our spiritual journeys inspire creative solutions for these seemingly overwhelming challenges [1]. While seeking guidance during such seismic traumas, meditations unveil profound insights into the nature of life and a miraculous knowledge of the universe. These quests for inner wisdom impart a sense of immense gratitude, awe, wonder, and connectedness that feels larger than life. A neuropeptide hormone, oxytocin, otherwise associated with reproduction and feelings of love and trust, emerges as a candidate key to unlocking our navigational inner wisdom [2]. Oxytocin is an elixir of whole body health and integral in a proposed gut microbe-immune-brain axis, at least in part through connections between microbes and the vagus nerve that stretches from brain to heart and gut [3].

Is it possible that ancestral microbes, microRNAs, and a 'love' hormone within us form the scientific threads of our inner wisdom?

Cutting edge science using human brain imaging has been linked spirituality with anatomical structures in the base of the brain, referred to as the hypothalamus [4]. In particular, a neuropeptide hormone, oxytocin, otherwise associated with reproduction and feelings of love and trust, spikes within neurons of the hypothalamus during meditation and religious practices. In scientific experiments, human subjects who received oxytocin supplements reported experiencing spiritual emotions including awe and gratitude [4]. Effects of this hormone extend far beyond our moods and spiritual connections. A profound boost in circulating oxytocin levels was first discovered with a human breast milk microbe imparting potent wound healing benefits in animal models via an elegant symbiosis mediated by the sprawling vagus nerve [3]. This vast visceral neural network is believed to be the basis for our 'gut feelings' and 'tingle in our heart'.

So it is possible that a seemingly spiritual vision is substantiated by science. But how would oxytocin produced by the brain reveal universal wisdoms to the spiritual traveler?

Reasoning that our ancestral past may be what is more commonly recognized as our instinctive behaviors, it is already understood that reproductive instincts of nursing and rearing young are mediated by oxytocin. In fact, female mice without prior births instinctively understand how to care for their young under the influence of oxytocin [5]. To the same extent, virginal male rats miraculously make better lovers after an oxytocin-drip, even though they have never watched a video [6]. From an evolutionary perspective, this oxytocin-revives-ancient-memories paradigm makes good sense.

But then how do instinctive memories get into our brains in the first place? Amazingly, scientific evidence exists for life experiences in mammals to be passed epigenetically from 
one generation to the next via microRNAs [7]. It is not just mom that contributes to this awesome inheritance handbook of helpful hints to save the family jewels. In this case, dad is crucial too, because sperm are continuously regenerating and provide an immediate environmental report. For example, dad encounters a fearsome spider and then his kids are afraid of spiders, too. Emerging data further point to miRNAs as last-minute edits within testicular epididymites making contributions to behaviors far beyond genetics alone [8].

In laboratory studies, such multigenerational memories encoded by RNAs endure for up to 80 generations in C. elegans worms [9]. This is not to say that humans have brains like worms; rather, that these data provide evidence of an innate mechanism that could be tweaked under certain conditions for mammalian neural networks to more effectively store and liberate massive archives of ancestral wisdom when needed, with minimal interference to our daily lives.

Let us say for a moment that all of this is true, and spirituality and wisdom of the ages boils down to the hugging molecules in our brains. It is rational that pivotal events in our survival, such as successful reproduction and fearsome life-threatening events would be saved in the family archives for a rainy day. Maybe this archive of experiences is compounded peripherally, too? As social beings, humans learn not only by our own actions, but also by watching and learning from others' mistakes [10,11]. Thus, our ancestral tapestry may be composed of a lifetime of memories of not only grandpa, but also his close friends or coworkers. One step further, perhaps ancestral diets and even microbial partnerships contribute miRNAs that convey information on bounty or danger. It seems far-fetched that foods would convey knowledge or emotions via miRNAs [4,12], but is it? A multigenerational transfer of such accumulated memories could help explain why many civilizations around the world have described experiencing earlier lives [13].

Are these ancestral experiences the roots of our compassion, empathy and altruism toward other creatures?

Additionally, what if our accumulated ancestral memories reflect more advanced yet extinct civilizations than we previously thought, ultimately inspiring social and technological revolutions in a repeating loop of groundhog days? Does connectedness with this spiritual realm help us rediscover our humanity? Did such ancestral knowledge inspire creations of visionaries like Nikola Tesla? Is this how Leonardo di Vinci proposed flying machines of the future-past?

While a virtual survival manual stored deep within our brains makes good sense for universal harmony, then how do we unlock this heirloom masterpiece? Emotional fear processing, in particular, is relegated to a portion of the brain, referred to as amygdala, adjacent to the hippocampus. Both the hippocampus and amygdala are littered with oxytocin receptors that stimulate recall of bundled memories [14]. This evidence linking the hippocampus and amygdala with oxytocin provides a scientific mechanism liberating downstream ancestral memories catalogued in neuronal networks. Knowing that oxytocin may likewise be boosted during meditation or prayer provides a possible portal to ancestral diaries. Following this logic one step further, the meditating mind struggles to put the knowledge archives into familiar themes, filling in the gaps, and imparting the feelings of a guiding voice or visiting an Akashic Record library. These treasures are unbundled and retrieved under the influence of oxytocin to convey resiliency for survival in life-anddeath situations.

Therefore, by following the stepping-stones of this scientific pathway, instincts in our brains are stored away on virtual library shelves in our mind. This strategy reduces the risk of overloading problem-solving brain circuitry occupied with everyday activities like driving a car. Oxytocin release connected with passion or pain tickles neurons to release their accumulated knowledge in times of need, for example, mother-infant survival [15] and societal attachments during life-and-death decisions in the human ancestral tapestry [16]. It is interesting that oxytocin has been implicated in neuronal plasticity [17], providing a scientific basis for more creative solutions to life-threatening situations. This combination 
may help to explain why people who meditate sometimes experience inexplicable leaps of creativity.

It is, indeed, an elegant symbiosis that microbial products derived from human milk are sufficient to upregulate hypothalamic oxytocin levels in host animals [18], a microbial hug of sorts, essentially passing a legacy of sociability and neurological stability to their offspring [19]. It is an intriguing possibility that these microbial muses contribute to a host collective, a nurturing holobiont of empathy and altruism passed from one generation to the next, for societal advancement and mutual survival. In this way seismic trauma may impart a shared sense of purpose and resiliency spanning generations [20,21]. Do antibiotics and processed diets deplete our vast repertoire of microbial passengers, ultimately changing what it means to be human $[22,23]$ ?

\section{Conclusions}

Taken together, this neuronal engagement forms the basis of our instincts, gut feelings, and intuition stored on the dusty shelves of our brains until times of need. In this way of thinking, a vast universal wisdom is actually a hippocampal directory of primal information accumulated across generations, and then passed to progeny via sexual reproduction, gestation, and nursing. These neurological archives help us navigate through difficult emotional and spatial journeys to find our way back to the safety of community. Perhaps meditations with our microbial muses summon our inner wisdoms for inspiration and salvation during challenging times. Mystical journeys reveal seemingly miraculous knowledge deeply rooted in our ancestral experiences. With feelings of gratitude, we thank our distant forebear holobionts for inner wisdoms that take care of us all.

Funding: This opinion received no external funding.

Institutional Review Board Statement: Not applicable.

Informed Consent Statement: Not applicable.

Data Availability Statement: Not applicable.

Conflicts of Interest: The author declares no conflict of interest.

\section{References}

1. Tedeschi, R.G.; Calhoun, L.G. The posttraumatic growth inventory: Measuring the positive legacy of trauma. J. Trauma. Stress 1996, 9, 455-471. [CrossRef] [PubMed]

2. Sharma, S.R.; Gonda, X.; Dome, P.; Tarazi, F.I. What's Love Got to do with it: Role of oxytocin in trauma, attachment and resilience. Pharmacol. Ther. 2020, 214, 107602. [CrossRef] [PubMed]

3. Poutahidis, T.; Kearney, S.M.; Levkovich, T.; Qi, P.; Varian, B.J.; Lakritz, J.R.; Ibrahim, Y.M.; Chatzigiagkos, A.; Alm, E.J.; Erdman, S.E. Microbial symbionts accelerate wound healing via the neuropeptide hormone oxytocin. PLoS ONE 2013, 8, e78898. [CrossRef]

4. Van Cappellen, P.; Way, B.M.; Isgett, S.F.; Fredrickson, B.L. Effects of oxytocin administration on spirituality and emotional responses to meditation. Soc. Cogn. Affect. Neurosci. 2016, 11, 1579-1587. [CrossRef] [PubMed]

5. Scott, N.; Prigge, M.; Yizhar, O.; Kimchi, T. A sexually dimorphic hypothalamic circuit controls maternal care and oxytocin secretion. Nature 2015, 525, 519-522. [CrossRef]

6. Gil, M.; Bhatt, R.; Picotte, K.B.; Hull, E.M. Oxytocin in the medial preoptic area facilitates male sexual behavior in the rat. Horm. Behav. 2011, 59, 435-443. [CrossRef] [PubMed]

7. Rodgers, A.B.; Morgan, C.P.; Leu, N.A.; Bale, T.L. Transgenerational epigenetic programming via sperm microRNA recapitulates effects of paternal stress. Proc. Natl. Acad. Sci. USA 2015, 112, 13699-13704. [CrossRef]

8. Sharma, U.; Sun, F.; Conine, C.C.; Reichholf, B.; Kukreja, S.; Herzog, V.A.; Ameres, S.L.; Rando, O.J. Small RNAs are trafficked from the epididymis to developing mammalian sperm. Dev. Cell 2018, 46, 481-494. [CrossRef]

9. Houri-Ze'Evi, L.; Korem, Y.; Sheftel, H.; Faigenbloom, L.; Toker, I.A.; Dagan, Y.; Awad, L.; Degani, L.; Alon, U.; Rechavi, O. A tunable mechanism determines the duration of the transgenerational small RNA inheritance in C. elegans. Cell 2016, 165, 88-99. [CrossRef]

10. Felix-Ortiz, A.; Burgos-Robles, A.; Bhagat, N.; Leppla, C.; Tye, K. Bidirectional modulation of anxiety-related and social behaviors by amygdala projections to the medial prefrontal cortex. Neuroscience 2016, 321, 197-209. [CrossRef] 
11. Allsop, S.A.; Wichmann, R.; Mills, F.; Burgos-Robles, A.; Chang, C.-J.; Felix-Ortiz, A.C.; Vienne, A.; Beyeler, A.; Izadmehr, E.M.; Glober, G.; et al. Corticoamygdala transfer of socially derived information gates observational learning. Cell 2018, 173, 1329-1342.e18. [CrossRef]

12. Hoban, A.E.; Stilling, R.M.; Moloney, G.M.; Moloney, R.D.; Shanahan, F.; Dinan, T.G.; Cryan, J.F.; Clarke, G. Microbial regulation of microRNA expression in the amygdala and prefrontal cortex. Microbiome 2017, 5, 1-11. [CrossRef]

13. White, C. Who wants to live forever? J. Cogn. Cult. 2017, 17, 419-436. [CrossRef]

14. Raam, T.; McAvoy, K.M.; Besnard, A.; Veenema, A.H.; Sahay, A. Hippocampal oxytocin receptors are necessary for discrimination of social stimuli. Nat. Commun. 2017, 8, 2001. [CrossRef]

15. Carter, C.S.; Porges, S.W. The biochemistry of love: An oxytocin hypothesis. EMBO Rep. 2013, 14, 12-16. [CrossRef]

16. Bernaerts, S.; Prinsen, J.; Berra, E.; Bosmans, G.; Steyaert, J.; Alaerts, K. Long-term oxytocin administration enhances the experience of attachment. Psychoneuroendocrinology 2017, 78, 1-9. [CrossRef]

17. Lee, S.-Y.; Park, S.-H.; Chung, C.; Kim, J.J.; Choi, S.-Y.; Han, J.-S. Oxytocin protects hippocampal memory and plasticity from uncontrollable stress. Sci. Rep. 2015, 5, 18540. [CrossRef] [PubMed]

18. Varian, B.J.; Poutahidis, T.; DiBenedictis, B.T.; Levkovich, T.; Ibrahim, Y.; Didyk, E.; Shikhman, L.; Cheung, H.K.; Hardas, A.; Ricciardi, C.E.; et al. Microbial lysate upregulates host oxytocin. Brain Behav. Immun. 2017, 61, 36-49. [CrossRef]

19. Buffington, S.A.; Di Prisco, G.V.; Auchtung, T.A.; Ajami, N.J.; Petrosino, J.F.; Costa-Mattioli, M. Microbial reconstitution reverses maternal diet-induced social and synaptic deficits in offspring. Cell 2016, 165, 1762-1775. [CrossRef] [PubMed]

20. Alkalay, S.; Sagi-Schwartz, A.; Wiseman, H. Increased empathy and helping behavior toward the mother in daughters of Holocaust survivors. Traumatology 2020, 26, 84-95. [CrossRef]

21. Dekel, S.; Mandl, C.; Solomon, Z. Is the Holocaust implicated in posttraumatic growth in second-generation Holocaust survivors? A prospective study. J. Trauma. Stress 2013, 26, 530-533. [CrossRef] [PubMed]

22. Rees, T.; Bosch, T.; Douglas, A.E. How the microbiome challenges our concept of self. PLoS Biol. 2018, 16, e2005358. [CrossRef] [PubMed]

23. Dowd, J.B.; Renson, A. "Under the skin" and into the gut: Social epidemiology of the microbiome. Curr. Epidemiol. Rep. 2018, 5, 432-441. [CrossRef] [PubMed] 